\title{
Implementation of Audiovisual Media in Improving Indonesian Learning Results About Writing Skills in SD Negeri 2 Penolih
}

\author{
A.R. Wulandari \\ SD Negeri 2 Penolih \\ muda65487@gmail.com
}

\section{Article History}

accepted $14 / 11 / 2020$

approved $21 / 11 / 2020$

published 26/11

\begin{abstract}
The purpose of this study was to improve the learning outcomes of students in the Indonesian Language Muple Writing Skills in Elementary School Class III with the learning model of Discovery Learning assisted by audiovisual media. The research conducted was a Classroom Action Research (CAR) in two cycles, with each cycle consisting of one meetings. The stages of each cycle are planning, implementing, observing and reflecting. Each meeting is carried out a pre test and post test to determine the progress of students. In the first cycle the students who completed after carrying out the post test were 58\%. In the second cycle students who completed after carrying out the post test were $75 \%$. These results indicate that the application of audiovisual media can improve student learning outcomes, especially Indonesian language muple in elementary schools
\end{abstract}

Keywords: Learning outcomes, discovery learning, audiovisual media

\section{Abstrak}

Tujuan dari penelitian ini adalah untuk meningkatkan hasil belajar peserta didik pada mupel Bahasa Indonesia pada Ketrampilan Menulis di Sekolah Dasar kelas III dengan model pembelajaran Discovery Learning berbantuan media audiovisual. Penelitian yang dilakukan adalah Penelitian Tindakan Kelas (PTK) sebanyak dua siklus, dengan setiap siklusnya terdiri dari satu pertemuan. Tahapan setiap siklusnya adalah perencanaan, pelaksanaan, observasi dan refleksi. Setiap pertemuan dilakukan pre test dan post test untuk mengetahui perkembangan peserta didik. Pada siklus I peserta didik yang tuntas setelah melaksanakan post test sebesar $58 \%$. Pada siklus II peserta didik yang tuntas setelah melaksanakan post test sebesar $75 \%$. Hasil ini menunjukan bahwa penerapan media audiovisual dapat meningkatkan hasil belajar peserta didik khususnya mupel Bahasa Indonesia di SD Negeri 2 Penolih

Kata kunci: Hasil belajar, discovery learning, media audiovisual

Social, Humanities, and Education Studies (SHEs): Conference Series https://jurnal.uns.ac.id/shes

p-ISSN 2620-9284

e-ISSN 2620-9292 


\section{PENDAHULUAN}

Pendidikan merupakan suatu kebutuhan penting untuk meningkatkan kualitas sumber daya manusia. Hal tersebut juga telah dicantumkan dalam Undang Undang Republik Indonesia No. 20 Tahun 2003 Tentang Sistem Pendidikan Nasional pada Pasal 1 disebutkan bahwa pendidikan adalah usaha sadar dan terencana untuk mewujudkan suasana belajar dan proses pembelajaran peserta didik secara aktif mengembangkan potensi dirinya untuk memiliki kekuatan spiritual, keagamaan, pengendalian diri, kepribadian, kecerdasan, akhlak mulia, serta ketrampilan yang diperlukan dirinya, masyarakat, bangsa, dan negara.

Belajar adalah aktivitas mental/psikis yang berlangsung dalam interaksi aktif dengan lingkungan yang menghasilkan perubahan-perubahan dalam pengetahuan, keterampilan dan sikap. Tujuan pendidikan tersebut dapat tercapai apabila guru mampu mewujudkan suatu proses belajar mengajar yang baik. Guru harus mampu mengetahui karakteriktistik peserta didik dan juga materi yang akan disampaikan. Hal tersebut dikarenakan peserta didik merasa tidak mampu berpikir secara abstrak, dikarenakan guru tidak menampilkan media-media yang dapat membantu peserta didik memahami materi.

Peningkatan penyebaran virus Covid 19 berdampak pada proses pembelajaran di sekolah. Untuk mengurangi penyebaran virus tersebut maka proses belajar mengajar di sekolah dilaksanakan secara daring. Pada penelitian tindakan kelas ini peneliti ingin meningkatkan hasil belajar peserta didik pada muatan pelajaran Bahasa Indonesia melalui media audiovisual karena pada pembelajaran sebelumnya yang hanya menggunakan aplikasi Whatsapp kurang berhasil.

Penelitian tindakan kelas adalah penelitian yang dilakukan oleh guru di kelasnya sendiri melalui refleksi diri dengan tujuan untuk memperbaiki kinerjanya sehingga hasil belajar peserta didik meningkat (Aqib. 2011).

Kesulitan peserta didik pada muatan pelajaran Bahasa Indonesia terletak pada penguasaan materi karena pembelajaran jarak jauh hanya menggunakan aplikasi Whatsapp. Data hasil ulangan harian peserta didik kelas 3 SD Negeri 2 Penolih menunjukkan dari 12 peserta didik, terdapat 5 peserta didik yang memenuhi KKM (Kriteria Ketuntasan Minimum) dan 7 peserta didik lainnya mendapatkan nilai kurang dari KKM. Nilai KKM dari muatan pelajaran Bahasa Indonesia adalah 70.

Hasil belajar peserta didik yang kurang diakibatkan oleh kelemahan guru dan peserta didik. Kelemahan guru tersebut adalah kurangnya kemampuan untuk memanfaatkan teknologi dalam pembelajaran jarak jauh yang dapat menarik perhatian peserta didik, kurangnya kemampuan untuk menciptakan suasana kelas daring yang menarik dan kurangnya kemampuan untuk memanfaatkan media-media pembelajaran yang inovatif. Sebaliknya kelemahan peserta didik adalah kesulitan memahami materi pembelajaran melalui pembelajaran daring.

Berdasarkan latar belakang yang telah diuraikan di atas, peneliti menganggap bahwa penggunaan model discovery learning berbantuan media audiovisual sangat diperlukan, sehingga perlu diterapkan ke dalam pembelajaran melalui penelitian yang berjudul "Penerapan Media Audiovisual Dalam Meningkatkan Hasil Belajar Bahasa Indonesia Tentang Keterampilan Menulis Kalimat Ungkapan Di Kelas 3 Tema 4 Sub Tema 1 Di SD Negeri 2 Penolih Tahun Ajaran 2020/2021"

\section{METODE}

Bagian ini disajikan jika artikel merupakan hasil penelitian (hasil kajian tidak perlu menyajikan bagian ini). Bagian ini disajikan maksimal 200 kata. Bagian ini dipaparkan jenis penelitian, data dan sumber data, teknik dan alat pengumpulan data, serta teknik analisi data yang digunakan.Penelitian ini adalah penelitian tindakan kelas (Classroom Action Research) dengan menerapkan Media audiovisual. Menurut Kurt Lewin dalam Kunandar (2011: 42) penelitian tindakan kelas ini terdiri dari empat tahapan dasar yaitu 
perencanaan (planning), pelaksanaan (acting), pengamatan (observing) dan refleksi (reflecting). Analisis penelitian ini adalah analisis deskriptif kuantitafif kualitatif dimana dalam penelitian ini selain penyajian hasil berupa data maupun angka peneliti juga menentukan bagaimana cara pengolahan hasil penelitian yakni dengan membuat analisisnya dengan menerapkan model penelitian Discovery learning Penelitian ini dilaksanakan pada peserta didik kelas III SD Negeri 2 Penolih Tahun Ajaran 2020/2021 selama dua siklus secara daring menggunakan aplikasi Zoom cloud meet dengan satu pertemuan disetiap siklusnya. Siklus I dilaksanakan pada tanggal 12 November 2020. Siklus II dilaksanakan pada tanggal 23 November 2020. Teknik pengumpulan data yang dilakukan dengan observasi dan tes, baik pre test maupun post test. Observasi meliputi observasi keterlaksanaan model pembelajaran Discovery learning, sikap peserta didik dan keterampilan. Untuk hasil belajar menggunakan tes melalui Google form.

\section{HASIL DAN PEMBAHASAN}

Pada siklus I pembelajaran dilaksanakan selama satu pertemuan, setiap pertemuan diadakan pre test dan post test. Untuk mengetahui perkembangan peserta didik selama pembelajaran. Siklus I membahas materi membuat kalimat ungkapan saran, dan penyelesaian masalah sederhana. Pembelajaran dengan model Discovery learning dilaksanakan dengan 6 langkah secara berurutan mulai dari Stimulation (Stimulasi/pemberian rangsangan), Problem statement (Pernyataan/Identifikasi masalah), Data Collection (Pengumpulan data), Data Proccessing (Pengolahan data), Verivication Data (Pembuktian), Generalization (Menarik kesimpulan). Berikut ini adalah hasil belajar peserta didik pada siklus I yang bisa dilihat pada tabel berikut.

Tabel 1. Hasil Peserta didik Siklus I

\begin{tabular}{ccccccccc}
\hline & \multicolumn{3}{c}{ Pre test } & \multicolumn{3}{c}{ Post test } \\
\cline { 2 - 9 } Siklus 1 & $\begin{array}{l}\text { Pesdik } \\
\text { tuntas }\end{array}$ & $\begin{array}{l}\text { Pesdik } \\
\text { belum } \\
\text { tuntas }\end{array}$ & $\begin{array}{l}\text { Pesdik } \\
\text { tuntas }\end{array}$ & $\begin{array}{l}\text { Pesdik } \\
\text { belum } \\
\text { tuntas }\end{array}$ \\
\cline { 2 - 9 } & Jml & $\%$ & Jml & $\%$ & Jml & $\%$ & Jml & $\%$ \\
\hline Pertemuan 1 & 5 & 42 & 7 & 58 & 7 & 58 & 5 & 42 \\
\hline
\end{tabular}

Berdasarkan tabel di atas maka terjadi peningkatan antara pre test dan post test pada pertemuan 1. Setiap individu peserta didik sudah mengalami peningkatan hasil belajarnya. Peserta didik mengalami peningkatan hasil belajar pada pertemuan 1. Ketuntasan klasikal juga mengalami peningkatan, pada pre test hanya terdapat 5 anak yang sudah tuntas, tetapi pada post test bertambah menjadi 7 anak yang sudah tuntas dengan Kriteria Ketuntasan Minimal (KKM) sebesar 70. Pada pertemuan 1 peserta didik yang sudah tuntas hanya ada 7 anak, Persentase ketuntasan klasikalnya meningkat, pada pertemuan 1 siklus I sebesar $58 \%$. Berdasarkan refleksi pada siklus I maka diputuskan untuk melanjutkan ke siklus II dikarenakan belum mencapai ketuntasan klasikal yang diharapkan. Siklus II membahas materi kalimat ungkapan saran/masukan dan penyelesaian masalah sederhana. Pembelajaran dengan model Discovery learning dilaksanakan dengan 6 langkah secara berurutan seperti siklus I. Berikut ini adalah hasil belajar peserta didik pada siklus II yang bisa dilihat pada tabel berikut. 
Tabel 2. Hasil Peserta didik Siklus II

\begin{tabular}{|c|c|c|c|c|c|c|c|c|}
\hline \multirow{3}{*}{ Siklus II } & \multicolumn{4}{|c|}{ Pre test } & \multicolumn{4}{|c|}{ Post test } \\
\hline & \multicolumn{2}{|c|}{$\begin{array}{l}\text { Pesdik } \\
\text { tuntas }\end{array}$} & \multicolumn{2}{|c|}{$\begin{array}{l}\text { Pesdik } \\
\text { belum } \\
\text { tuntas }\end{array}$} & \multicolumn{2}{|c|}{$\begin{array}{l}\text { Pesdik } \\
\text { tuntas }\end{array}$} & \multicolumn{2}{|c|}{$\begin{array}{l}\text { Pesdik } \\
\text { belum } \\
\text { tuntas }\end{array}$} \\
\hline & $\mathrm{Jml}$ & $\%$ & $\mathrm{Jml}$ & $\%$ & $\mathrm{Jml}$ & $\%$ & $\mathrm{Jml}$ & $\%$ \\
\hline Pertemuan 1 & 7 & 58 & 5 & 42 & 9 & 75 & 3 & 25 \\
\hline
\end{tabular}

Berdasarkan tabel di atas maka terjadi peningkatan antara pre test dan post test pada pertemuan 1. Setiap individu peserta didik sudah mengalami peningkatan hasil belajarnya. Ketuntasan klasikal juga mengalami peningkatan, pada pre test hanya terdapat 7 anak yang sudah tuntas, tetapi pada post test bertambah menjadi 9 anak yang sudah tuntas dengan Kriteria Ketuntasan Minimal (KKM) sebesar 70. Pada pertemuan 1 peserta didik yang sudah tuntas ada 9 anak, Persentase ketuntasan klasikalnya meningkat, yaitu $75 \%$ Setelah melakukan refleksi pada siklus II, maka diputuskan untuk melanjutkan pada siklus III. Hal ini dilakukan agar mengetahui sejauh mana penerapan media audiovisual untuk meningkatkan hasil belajar peserta didik tidak hanya meningkatkan tetapi juga mempertahankan hasil belajar peserta didik.

Hasil penelitian tentang tingkat ketercapaian ketuntasan belajar peserta didik dalam menulis kalimat ungkapan dapat dilihat pada grafik berikut:

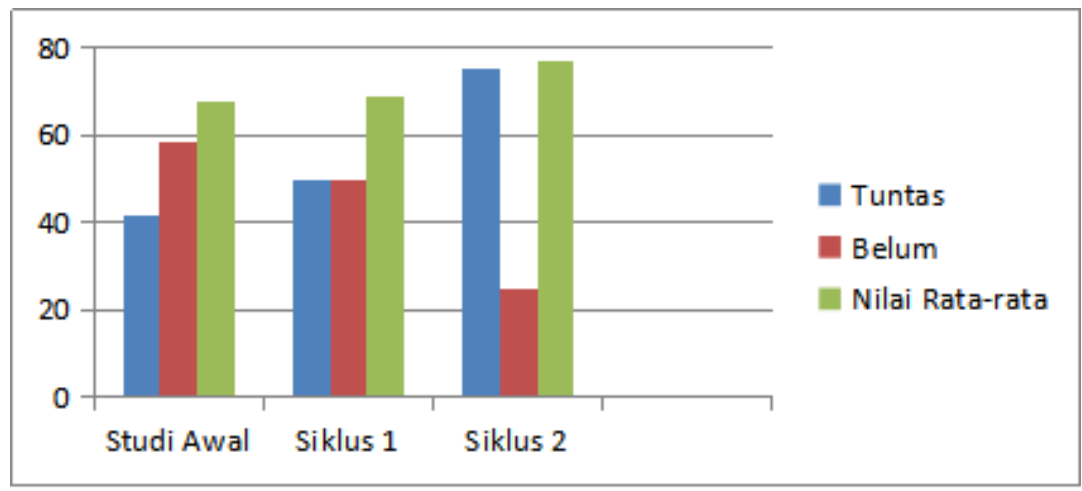

Gambar 1. Perbandingan Angka Ketuntasan Peserta didik dan Rata-rata Nilai Tes Pengetahuan Terhadap Keterampilan menulis Kalimat Ungkapan pada Tiap Siklusnya

Dari gambar dapat diperoleh keterangan angka ketuntasan belajar peserta didik dan rata-rata nilai pengetahuan pada tiap siklus mengalami peningkatan.

Dari dua siklus yang sudah dilaksanakan selama 2 pertemuan dapat dipastikan bahwa model pembelajaran Discovery learning berbantuan media audiovisual dapat meningkatkan hasil belajar peserta didik pada mupel Bahasa Indonesia Kelas III di SD Negeri 2 Penolih.

\section{SIMPULAN}

Penerapan media audiovisual dapat meningkatkan hasil belajar Bahasa Indonesia pada ketrampilan menulis kalimat ungkapan saran pada kelas III SD Negeri 2 Penolih. Peningkatan yang terjadi karena adanya kesan pembelajaran yang mendalam dari peserta didik tehadap materi yang diajarkan melalui setiap sintak yang dilalui. Peserta didik akan selalu teringat akan materi yang diajarkan dikarenakan mereka menemukan dan menyimpulkan sendiri pengetahuan mereka pada saat 
menyimak media audiovisual. Berdasarkan penelitian yang telah dilaksanakan salah satu model pembelajaran yang harus dikuasai guru adalah Discovery learning karena model ini sangat cocok digunakan dalam keadaan pandemi seperti ini, apalagi dalam kondisi belajar dari rumah. Peserta didik akan memahami konsep, arti, dan hubungan melalui proses intuitif untuk akhirnya sampai kepada suatu kesimpulan sendiri melalui media audiovisual yang disajikan guru.

\section{DAFTAR PUSTAKA}

Andi Prastowo, Panduan Kreatif Membuat Bahan Ajar Inovatif, Yoyakarta: Diva Press, 2014

Aqib, Zainal, dkk. 2011. Penelitian Tindakan Kelas untuk Guru SD, SLB, dan TK. Bandung: Yrama Widya.

Azhar Arsyad, Media Pembelajaran Jakarta : Raja grafindo Perkasa, 2009

Kementrian Pendidikan dan Kebudayaan RI. (2011). Peraturan Mendiknas tentang Satuan Pengawasan Internal (Permendiknas Nomor 47 tahun 2011). Jakarta: Penulis.

Kemmis S dan Mc.Taggart. 1992. The Action Research Planner. Victoria: Deakrin University.

Trianto. 2009. Mendesain Model Pembelajaran Inovatif Progresif. Surabaya: Kencana. 